\title{
A PRESERVATIVE FOR URINE SPECIMENS IN TRANSIT TO THE BACTERIOLOGICAL LABORATORY
}

\author{
C. R. Amirs ANd ANDrés Corpas \\ Department of Pathology, Toronto East General and Orthopaedic Hospital, \\ Toronto 13, Canada
}

A URINE specimen intended for bacteriological examination is often kept at room temperature for many hours before it is cultured. During this period bacteria present in the specimen rapidly increase in number because urine, as has long been known, is an excellent culture medium. Pathogens originating in the urinary tract will increase, but so will contaminants derived from the lower urethra and external surface of the genitalia. Bacteriological investigation of such specimens is a waste of time and reports based on the results obtained may be highly misleading.

One way of overcoming this difficulty is to prevent bacterial growth without at the same time diminishing the viability of the organisms originally present. This has been accomplished by adding sodium chloride as a bacteriostatic agent and polyvinylpyrrolidone (PVP) as a protective colloid to maintain the suspension stability of the bacterial cells. The results obtained by this method, both in laboratory experiments and in clinical practice, are here presented.

\section{MATERIALS AND METHODS}

The organisms employed were recent isolates of Escherichia coli (17 strains), Aerobacter aerogenes, Proteus vulgaris, Staphylococcus epidermidis (two strains each), Pseudomonas aeruginosa and an enterococcus (one strain each). All had been isolated from the urine of patients reported to be suffering from pyelitis or cystitis. A series of 10 -fold dilutions was prepared from a nutrient broth culture in the early logarithmic phase of growth. The dilutions from $10^{-1}$ to $10^{-4}$ were made in normal Seitz-filtered sterile urine and the $10^{-5}$ to $10^{-12}$ dilutions in nutrient broth. The tubes were then incubated at $37^{\circ} \mathrm{C}$ and examined the following morning for visible growth. Plate counts were also performed by the method of Miles, Misra and Irwin (1938). For the survival tests the $10^{-4}$ dilution, which usually contained about $10^{5}$ living cells per $\mathrm{ml}$, was dispensed into small screw-cap vials of $10 \mathrm{ml}$ capacity containing the requisite amount of preservative in either solid or liquid form. One vial of experimentally infected urine was similarly diluted with sterile physiological saline solution to act as a control. Urine and preservative were well mixed and then held at room temperature $\left(22^{\circ}-24^{\circ} \mathrm{C}\right)$ in the dark. $0.5 \mathrm{ml}$-volumes were removed immediately after mixing, and at 24-hr intervals thereafter up to a maximum of 7 days. Most of the experiments were terminated after 4 days. Viable counts were performed on each daily sample by using plate counts and dilution end-points as described above.

\section{Laboratory studies}

Preservative. A series of experiments was first performed to determine the optimum bacteriostatic concentration of $\mathrm{NaCl}$. Several different strains of $E$. coli and other urinary pathogens were used at $\mathrm{NaCl}$ levels ranging from 3 to 12 per cent. The best survival figures were obtained with a concentration of $9.0 \mathrm{~g}$ of salt in $100 \mathrm{ml}$ of urine. A further improvement, to the extent of about one $\log _{10}$ dilution, was achieved by adding PVP in a concentration of $1 \cdot 0-5 \cdot 0$ per cent. The effect of PVP in aiding dispersion of the bacteria in salt-urine mixtures was readily demonstrated by examination of wet-mount preparations with the darkfield microscope.

Received 12 Feb. 1970; accepted 20 Oct. 1970.

J. MED. MICROBIOL.-VOL. 4 (1971) 
The results of one representative experiment are presented graphically in the figure. The other bacterial species included in the complete series of 25 experiments gave similar results, even in the case of the two Staph. epidermidis strains, which were expected to show some growth in the presence of 9.0 per cent. $\mathrm{NaCl}$.

The formula finally chosen was: $\mathrm{NaCl}$, reagent quality $30 \mathrm{~g}$, polyvinylpyrrolidone, reagent quality $3 \mathrm{~g}$, water to $100 \mathrm{ml}$.

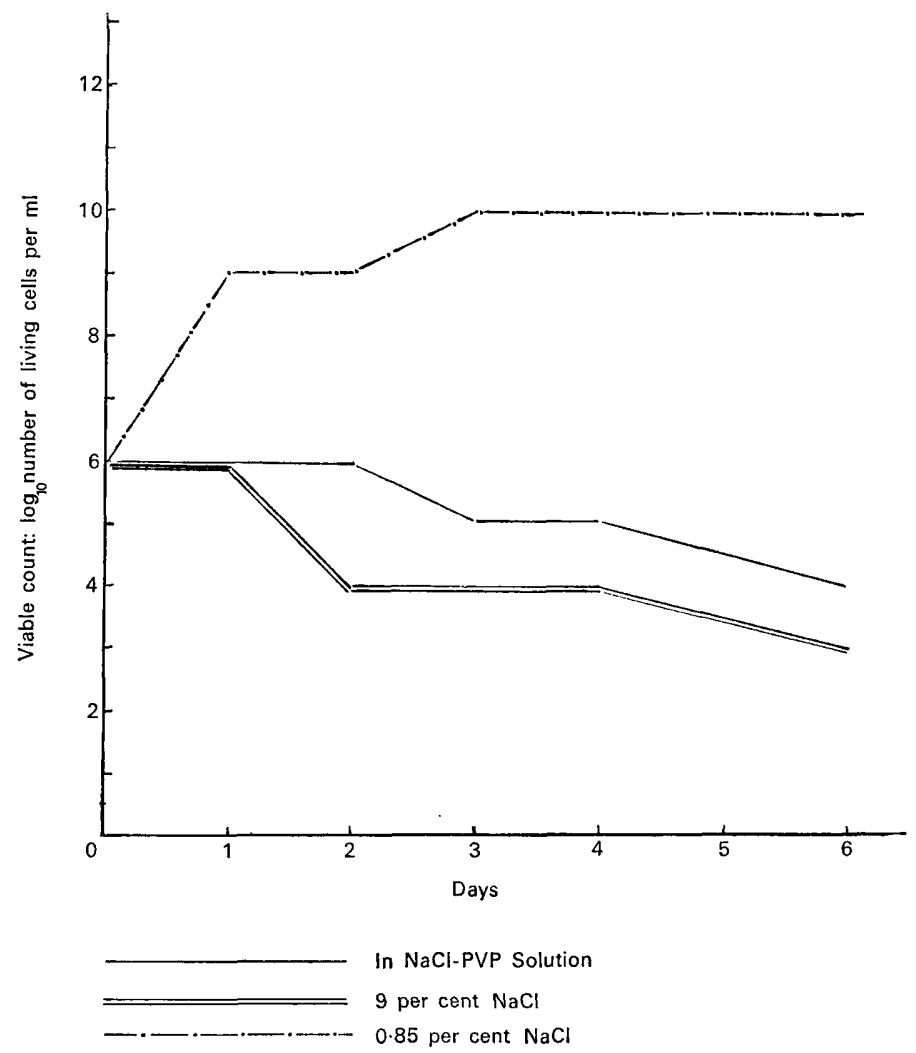

FIGURE.-Survival of Escherichia coli in urine preserved with: NaCl-polyvinylpyrrolidone solution; 9 per cent. $\mathrm{NaCl} ; 0.85$ per cent. $\mathrm{NaCl}$.

This almost saturated $\mathrm{NaCl}$ solution is self-sterilising except for halophilic bacteria and spore-bearers. If sterility is required this can be achieved by autoclaving in the usual manner. This causes separation into layers but a uniform solution is readily established by shaking the flask when it has returned to room temperature.

Preservation of clinical specimens. The preservative was dispensed in 3-ml volumes into 10-ml screw-cap vials and urine added up to the neck. A calibrated 0.001-ml platinum loop (Hoeprich, 1960; Greenberg et al., 1965) was used to plate both the preserved specimen and the control on nutrient blood agar at 2-hr intervals, from 0 to $8 \mathrm{hr}$ after collection. Mid-stream urine from hospital patients believed to have a urinary tract infection was collected in sterile wide-mouth jars after cleansing the external genitalia with soap and water. Immediately after it had been voided the urine was poured into a $10-\mathrm{ml}$ vial containing $3 \mathrm{ml}$ of preservative solution. A similar vial containing $3 \mathrm{ml}$ of sterile 0.85 per cent. $\mathrm{NaCl}$ solution was filled with the same urine to act as a control. It will be noted that there is a 1 in 1.4 dilution of the urine; this can be allowed for if desired. 


\section{RESULTS}

Some specimens were sterile, either because the patient was not suffering from a urinary tract infection or because he had already received an antibiotic, whilst others yielded a spreading growth of Proteus. When these unsatisfactory experiments, 33 in all, had been eliminated from the series there remained 69 specimens, which were divided into the following categories.

A. In 53 patients, the freshly voided urine, both preserved and control samples, showed more than 100,000 viable bacteria per $\mathrm{ml}$ (100 or more colonies per plate). Only one bacterial species was observed at that time. In later samples the bacterial count of the preserved specimen was maintained at a constant level whereas that of the control specimen rapidly increased to yield a confluent and often mixed growth. These findings permitted a report of significant bacteriuria.

B. In six patients, the preserved specimen maintained a viable count between 10,000 and 100,000 bacteria per $\mathrm{ml}$ during the observation period of 6 or $8 \mathrm{hr}$. The control specimen showed a progressive increase in the viable count to more than 100 -fold during the same period. The report was entered accordingly as doubtfully significant.

C. In one case only, the viable count of the preserved specimen remained below 10,000 per $\mathrm{ml}$, whilst that of the control specimen rapidly increased. This was reported as insignificant bacteriuria.

D. In nine patients, the preserved urine showed a slow decline in the number of viable bacteria during the 6- or 8-hr period of observation, whereas in the control the number rapidly increased. This decrease was less than one log and the significance of the viable count was, therefore, not altered. In each case a heavy cloud of insoluble phosphates had formed in the urine on standing.

\section{The preservative in routine use}

Introduction of the preservative as a routine procedure for the submission of all urine specimens on which a bacteriological examination was required was not attended by any difficulty, and the method has now been in general use for $18 \mathrm{mth}$. Previously, results were reported as slight, moderate or heavy growth, about a half falling into the moderate category, which left the physician in doubt about the significance of the findings. With the new procedure it was felt justifiable to perform colony counts and to interpret these as insignificant $\left(<10^{4}\right.$ cells per $\left.\mathrm{ml}\right)$, doubtful $\left(10^{4}-10^{5}\right.$ cells per $\left.\mathrm{ml}\right)$ and significant $\left(>10^{5}\right.$ cells per $\mathrm{ml}$ ) according to the commonly accepted standards recommended by Kass (1956).

It was hoped that a solid preservative could be prepared commercially in tablet form. Compressed tablets were made, but it was found that these did not dissolve quickly enough in the urine specimen unless the vial was shaken for some time.

\section{Discussion}

Porter and Brodie (1969) have recently recommended the use of boric acid as a urine preservative. We have carried out a number of experiments to compare the salt-PVP and the boric acid methods and found that they gave very similar results. Boric acid has the disadvantage of dissolving very slowly, making it necessary to shake the vial for $15 \mathrm{~min}$. to effect solution. A further disadvantage of boric acid is its toxicity (see Gleason et al., 1969). Moreover, the dispensing of small weighed amounts of this substance into our $10-\mathrm{ml}$ vials was found to be a tedious and time-consuming procedure.

The NaCl-PVP solution can be used for the preservation of other specimens such as joint fluid and pleural effusions. Tubercle bacilli in sputum remain viable in the solution for at least 8 days with no appreciable drop in infectivity.

\section{SUMMARY}

Bacteriological examination of the urine is often rendered useless by overgrowth of organisms, which occurs while the specimen is in transit from clinic to laboratory. A delay 
of $4 \mathrm{hr}$ at room temperature is often sufficient to produce a 100 -fold increase in the viable bacterial count. It is shown that this overgrowth can be prevented by adding to the freshly collected urine a mixed solution of $\mathrm{NaCl}$ and polyvinylpyrrolidone to give final concentrations of 9.0 per cent. $\mathrm{NaCl}$ and 1.0 per cent. PVP. By this means it is possible to perform quantitative bacteriological tests on mid-stream specimens that have been delayed in transit for $24 \mathrm{hr}$ or longer.

\section{REFERENCES}

Gleason, M. N., Gosselin, R. E., Hodge, H. C., ANd Smith, R. P. 1969. Clinical toxicology of commercial products; acute poisoning, 3rd ed., Baltimore.

Greenberg, N. D., Stamler, J., Zackler, J., ANd Andelman, S. L. 1965. Detection of urinary tract infections in pregnant women. Publ. Hlth Rep., Wash., 80, 805.

HoEPRICH, P. D. 1960 . Culture of the urine. J. Lab. Clin. Med., 56, 899.

Kass, E. H. 1956. Asymptomatic infections of the urinary tract. Trans. Assoc. Amer. Physns, 69, 56.

Miles, A. A., Misra, S. S., AND Irwin, J. O. 1938. The estimation of the bactericidal power of the blood. J. Hyg., Camb., 38, 732.

PoRTER, I. A., AND BRODIE, J. 1969. Boric acid preservation of urine samples. Br. Med. J., 2,353 . 